\title{
INSPEKSI SANITASI LINGKUNGAN SEKOLAH DI SMA NEGERI 1 MARTAPURA
}

\author{
Hendra R, Darmiah, Imam Santoso, Erminawati \\ Poltekkes Kemenkes Banjarmasin Jurusan Kesehatan Lingkungan \\ Jl. H. Mistar Cokrokusumo No.1A Banjarbaru Kalimantan Selatan 70714 \\ E-mail: darmiah0708@gmail.com
}

\begin{abstract}
The Sanitation Inspection in SMA Negeri 1 Martapura. Public places have potential as a place of transmission of disease, pollution, or other health problems. Places or public service facilities that are obliged to carry out environmental sanitation include public places are managed commercially or public services that have a high intensity of number and time of visit, one of which is the school environment. The study aimed to find out the picture of school environmental sanitation in SMA Negeri 1 Martapura with research variables; Cleanliness and neatness of building space, condition of toilet, building construction, and environmental coaching. Research method's observational, and measurement of environmental quality (lighting and noise). Processing and data analysis done descriptively. The result of measurement of building cleanliness variables obtained value of 140 points $(70 \%)$, toilet condition variable 585 points $(73.12 \%)$, building construction variables $575(95,83 \%)$ and environmental coaching 2,060 points $(85,83 \%)$. Overall assessment of school environmental santitasi obtained points 3,360 points (84\%) so that included in the category of healthy schools. It is recommended that schools at WC/KM at schools equip with lights for lighting in WC/KM to be bright, sewage discharges with closed construction, students better maintain cleanliness and tidiness of classes, curtains when learning activities are opened, and more activate the activities of clean Friday.
\end{abstract}

Keywords: Inspection; Sanitation; School Environment.

Abstrak : Inspeksi Sanitasi Lingkungan Sekolah Di Sma Negeri 1 Martapura. Tempattempat umum memiliki potensi sebagai tempat terjadinya penularan penyakit, pencemaran, ataupun gangguan kesehatan lainnya. Tempat atau sarana layanan umum yang wajib menyelenggarakan sanitasi lingkungan antara lain tempat umum dikelola secara komersial atau layanan umum yang memiliki intensitas jumlah dan waktu kunjungannya tinggi, salah satunya adalah lingkungan sekolah. Penelitian bertujuan mengetahui gambaran sanitasi lingkungan sekolah di SMA Negeri 1 Martapura dengan variabel penelitian; kebersihan dan kerapian ruang bangunan, kondisi WC/KM, konstruksi bangunan, dan pembinaan lingkungan. Metode penelitian observasional, dan pengukuran kualitas lingkungan (pencahayaan dan kebisingan). Pengolahan dan analisis data dilakukan secara deskiptif. Hasil pengukuran variabel kebersihan ruang bangunan memperoleh nilai 140 poin (70\%), variabel kondisi WC/KM 585 poin (73,12\%), variabel konstruksi bangunan 575 (95,83\%) dan variabel pembinaan lingkungan 2.060 poin $(85,83 \%)$. Secara keseluruhan penilaian santitasi lingkungan sekolah memperoleh poin 3.360 poin $(84 \%)$ sehingga masuk dalam kategori sekolah sehat. Disarankan pada pihak sekolah pada WC/KM di sekolah melengkapi dengan lampu agar pencahayaan didalam WC/KM menjadi terang, saluran pembuangan air limbah dengan konstruksi tertutup, para siswa/i lebih menjaga kebersihan dan kerapian kelas, korden pada saat kegiatan belajar dibuka, dan lebih mengefektifkan kegiatan jum'at bersih.

Kata Kunci: Inspeksi; Sanitasi; Lingkungan Sekolah.

\section{PENDAHULUAN}

Tempat atau sarana layanan umum yang wajib menyelenggarakan sanitasi lingkungan antara lain, tempat umum yang dikelola secara komersial, tempat yang memfasilitasi terjadinya penularan penyakit, atau tempat layanan umum yang memiliki intensitas jumlah dan waktu kunjungannya tinggi [1]. Lingkungan memiliki peran yang penting 
dalam mempengaruhi kondisi kesehatan manusia sehingga kondisi sehat (prepatogenesis) berkembang menjadi kondisi sakit (pathogenesis). Peran ini ditunjukan melalui keseimbangan hubungan tiga faktor yang saling mempengaruhi yaitu penyebab penyakit (agent), penjamu (host), dan lingkungan (environment) [2]. Diantara banyaknya lingkungan tempat umum yang ada salah satunya adalah lingkungan sekolah. Sekolah dan lingkungannya yang sehat sangat kondusif untuk berperilaku sehat bagi anak-anak [3]. Menurut UU No. 36 Tahun 2009 pasal 79 tentang kesehatan bahwa "Kesehatan sekolah diselenggarakan untuk meningkatkan kemampuan hidup sehat peserta didik dalam lingkungan hidup sehat, sehingga peserta didik dapat belajar dan tumbuh kembang secara harmonis dan optimal menjadi sumber daya manusia yang berkualitas." [4].

Berdasarkan Peraturan Menteri Pendidikan Nasional Republik Indonesia Nomor 57 tahun 2009 tentang pemberian bantuan pengembangan sekolah sehat, sekolah sehat adalah sekolah yang bersih, hijau, rindang, aman dan nyaman, peserta didiknya sehat, aktif dan bugar, serta berperilaku hidup bersih dan sehat [5].

Di Kabupaten Banjar terdapat 18 SMA negeri maupun swasta, 5 sekolah berada di kota Martapura. Salah satunya adalah SMA Negeri 1 Martapura. Sebagai sekolah favorit dan unggulan, jumlah siswa dalam kurun waktu 4-5 tahun terakhir cenderung meningkat, bisa dilihat dari pertambahan jumlah kelas dari 6 menjadi 9 kelas untuk setiap tingkatnya, oleh karena itu kondisi lingkungan sekolah yang bersih, aman, nyaman dan sehat sangat perlu diciptakan, agar menunjang dalam proses pembelajaran dan aktivitas penunjang lainnya, selain itu lokasi sekolah yang berada di tengah kota dan permukiman berpotensi menjadi masalah apabila ada terjadi kasus penyakit berbasis lingkungan sehingga berpotensi menularkan penyakit dari sekolah terhadap lingkungan permukiman sekitar ataupun sebaliknya, dalam kurun waktu beberapa tahun terkahir lingkungan sekolah sering mengalami banjir ketika musim hujan

\section{BAHAN DAN CARA PENELITIAN}

Metode penelitian yang digunakan deskriftif, bertujuan untuk melihat gambaran sanitasi sekolah dalam suatu populasi tertentu. Desain penelitian ini bersifat observasional dengan rancangan cross sectional [6]. Teknik pengambilan sampel secara proporsional random sampling [7]. Pada ruang kelas dan $\mathrm{WC} / \mathrm{KM}$, yaitu masing-masing $50 \%$ dari total populasi unit, yaitu untuk ruang kelas ada 13 ruang dan $13 \mathrm{WC} / \mathrm{KM}$, yang diperoleh daripopulasi yang diberi kode dan secara acak diambil dalam kondisihomogen, sedangkan nuntuk unit lainnya seperti ruang guru, perpustakaan, laboratorium, tempat ibadah, unit kesehatan sekolah (UKS) dan ruang bimbingan konseling menggunakan total sampel. Variabel penelitian: kebersihan dan kerapian ruang bangunan, kondisi WC/KM, konstruksi bangunan, dan pembinaan lingkungan. Data dikumpulkan menggunakan form observasi wawancara dan pengukuran dilakukan pada siang hari. Data dinalisis secara deskriptif berpedoman pada Kepmenkes 1429/Menkes/SK/XII/ 2006 tentang pedoman penyelenggaraan kesehatan lingkungan sekolah [8].

Penilaian sanitasi sekolah dibagi dalam 3 kategori. Untuk menentukan besar nilai rentang (range) adalah nilai tertinggi dikurang nilai terendah dibagi jumlah kategori [9], maka diperoleh perhitungan $(4.000-1.140=2.860 / 3=$ 953). Sekolah dinyatakan sehat apabila skore 3.048-4.000, kurang sehat 2.0943.047, dan tidak sehat 1.140-2.093.

\section{HASIL PENELITIAN DAN PEMBAHASAN \\ 1. Kebersihan dan kerapian ruang bangunan}


Tabel 1. Hasil pemeriksaan kebersihan dan kerapian ruang bangunan

\begin{tabular}{clcc}
\hline & & \multicolumn{2}{c}{ Item Penilaian } \\
No & & Kebersihan & Kerapian \\
\hline 1 & Ruang kelas 1 & Ya & Tidak \\
2 & Ruang kelas 2 & Ya & Ya \\
3 & Ruang kelas 3 & Ya & Ya \\
4 & Ruang kelas 4 & Ya & Ya \\
5 & Ruang kelas 5 & Ya & Ya \\
6 & Ruang kelas 6 & Ya & Ya \\
7 & Ruang kelas 7 & Ya & Ya \\
8 & Ruang kelas 8 & Tidak & Tidak \\
9 & Ruang kelas 9 & Ya & Ya \\
10 & Ruang kelas 10 & Ya & Tidak \\
11 & Ruang kelas 11 & Ya & Ya \\
12 & Ruang kelas 12 & Ya & Ya \\
13 & Ruang kelas 13 & Ya & Ya \\
14 & Laboratorium 1 & Ya & Ya \\
15 & Laboratorium 2 & Ya & Ya \\
16 & Laboratorium 3 & Ya & Ya \\
17 & Laboratorium 4 & Ya & Ya \\
18 & Laboratorium 5 & Ya & Ya \\
19 & Perpustakaan & Ya & Ya \\
20 & Ruang Guru & Ya & Ya \\
21 & Mushola & Ya & Ya \\
22 & Unit Kesehatan Sekolah & Ya & Ya \\
23 & Ruang BK & Ya & Ya \\
\hline
\end{tabular}

Tabel 1 menunjukkan bahwa kondisi kebersihan dan kerapian ruang bangunan sekolah yang berjumlah 23 ruang, terdapat 1 ruang yang kondisinya kurang bersih dan 3 ruang kondisinya kurang tertata rapi, yaitu pada ruang kelas, untuk ruang lainya kebersihan dan kerapiannya sudah baik.

Tabel 2. Hasil pemeriksaan ventilasi ruang bangunan

\begin{tabular}{|c|c|c|c|c|}
\hline No & Unit & Persyaratan & Hasil & Keterangan \\
\hline 1 & Ruang kelas 1 & & $5 \%$ & + kipas \\
\hline 2 & Ruang kelas 2 & & $5 \%$ & + kipas \\
\hline 3 & Ruang kelas 3 & & $10 \%$ & + kipas \\
\hline 4 & Ruang kelas 4 & & $10 \%$ & + kipas \\
\hline 5 & Ruang kelas 5 & & $10 \%$ & + kipas \\
\hline 6 & Ruang kelas 6 & & $10 \%$ & + kipas \\
\hline 7 & Ruang kelas 7 & & $5 \%$ & + kipas \\
\hline 8 & Ruang kelas 8 & & $5 \%$ & + kipas \\
\hline 9 & Ruang kelas 9 & & $5 \%$ & + kipas \\
\hline 10 & Ruang kelas 10 & & $5 \%$ & + kipas \\
\hline 11 & Ruang kelas 11 & & $10 \%$ & + kipas \\
\hline 12 & Ruang kelas 12 & & $10 \%$ & + kipas \\
\hline 13 & Ruang kelas 13 & & $10 \%$ & + kipas \\
\hline 14 & Laboratorium 1 & & & kipas + blower \\
\hline 15 & Laboratorium 2 & & & kipas + blower \\
\hline
\end{tabular}




$\begin{array}{ll}16 & \text { Laboratorium 3 } \\ 17 & \text { Laboratorium 4 } \\ 18 & \text { Laboratorium 5 } \\ 19 & \text { Perpustakaan } \\ 20 & \text { Mushola } \\ 21 & \text { Ruang guru } \\ 22 & \text { Ruang BK } \\ 23 & \text { UKS }\end{array}$

Tabel 2 menunjukkan kondisi ventilasi alamiah pada ruang kelas semuanya tidak mencapai persyaratan yaitu $20 \%$ dari luas lantai, hasil pemeriksaan hanya sekitar 5 - 10\% dari luas lantai. Sedangkan di unit laboratorium kondisi ventilasi alamiah tidak berfungsi, tetapi diruang tersebut dilengkapi dengan AC, kipas dan blower, sehingga dapat menjamin keluar masuk aliran udara. Ventilasi pada 6 ruang kelas tidak cross ventilation, 7 kelas cross ventilation, tetapi tidak memiliki kawat kasa untuk mencegah masuknya serangga atau binatang pengganggu serta pada setiap kelas luas ventilasi tidak mencapai standar Kepmenkes RI Nomor 1429/Menkes/SK/XII/ 2006 yaitu 20\% dari luas lantai. Tidak cukupnya ventilasi akan menyebabkan kelembaban udara di dalam ruangan naik karena terjadinya proses penguapan oleh cairan dari kulit kipas + blower

$\mathrm{AC}+$ blower

$\mathrm{AC}+$ blower

$\mathrm{AC}+$ blower

+kipas

$\mathrm{AC}+$ blower

$\mathrm{AC}+$ blower

$\mathrm{AC}+$ blower

dan penyerapan [10], akan tetapi pihak sekolah telah melakukan upaya dengan melengkapi setiap kelas dengan 2 fan (kipas angin) sehingga kondisi diruang kelas tidak terasa panas (tidak lembab), ventilasi yang baik mempunyai ukuran $\pm 10-20 \%$ dari luas lantai, ventilasi yang baik akan memberikan udara segar dari luar, suhu optimum $22-24^{\circ} \mathrm{C}$, dan kelembaban $60 \%(10)$, atau lubang ventilasi tetap minimum 5\% dari luas lantai [11]. Ventilasi yang cukup menyebabkan hawa ruangan baik dan nyaman, karena Ventilasi ruangan selain bermanfaat untuk sirkulasi udara juga tempat masuknya sinar matahari serta dapat mempengaruhi kelembaban dalam ruangan $^{8}$. Untuk menjaga kualitas udara di dalam ruangan kelembaban yang berasal dari dinding yang basah atau lantai yang lembab, harus dihindarkan [12].

Tabel 3. Hasil pengukuran pencahayaan ruang bangunan

\begin{tabular}{|c|c|c|c|c|}
\hline No & Unit & Persyaratan & Hasil & Keterangan \\
\hline 1 & Ruang kelas 1 & & 110 & Korden tertutup \\
\hline 2 & Ruang kelas 2 & & 101 & Korden tertutup \\
\hline 3 & Ruang kelas 3 & & 223 & Korden tertutup sebagian \\
\hline 4 & Ruang kelas 4 & & 105 & Korden tertutup \\
\hline 5 & Ruang kelas 5 & & 104 & Korden tertutup \\
\hline 6 & Ruang kelas 6 & & 121 & Korden terutup + ada pohon \\
\hline 7 & Ruang kelas 7 & & 201 & Korden tertutup sebagian \\
\hline 8 & Ruang kelas 8 & & 102 & Korden tertutup \\
\hline 9 & Ruang kelas 9 & & 86 & Korden terutup + ada pohon \\
\hline 10 & Ruang kelas 10 & & 88 & Korden terutup + ada pohon \\
\hline 11 & Ruang kelas 11 & & 226 & Korden tertutup sebagian \\
\hline 12 & Ruang kelas 12 & & 211 & Korden tertutup sebagian \\
\hline 13 & Ruang kelas 13 & & 234 & Korden tertutup sebagian \\
\hline 14 & Laboratorium 1 & & 201 & Tidak tertutup korden \\
\hline 15 & Laboratorium 2 & & 215 & Tidak tertutup korden \\
\hline 16 & Laboratorium 3 & & 250 & Tidak tertutup korden \\
\hline 17 & Laboratorium 4 & & 44 & Korden terutup + ada pohon \\
\hline
\end{tabular}




\begin{tabular}{|c|c|c|c|c|}
\hline 18 & Laboratorium 5 & & 37 & Korden terutup + ada pohon \\
\hline 19 & Perpustakaan & & 238 & Korden tertutup sebagian \\
\hline 20 & Ruang guru & & 260 & Korden terbuka \\
\hline 21 & Ruang BK & & 147 & Korden terbuka sebagian \\
\hline 22 & UKS & & 35 & Korden tertutup \\
\hline 23 & Mushola & $100 \operatorname{lux}$ & 105 & Korden terbuka \\
\hline
\end{tabular}

Tabel 3 menunjukkan dari total 23 ruangan yang dilakukan pengukuran terdapat $11 \quad(47,82 \%)$ ruangan yang intensitasnya sudah mencapai persyaratan, ruang bangunan yang belum memenuhi persyaratan dikarenakan pada saat pengukuran dilapangan terdapat korden yang menutupi ruangan, disekitar ruangan terdapat pepohonan sehingga pencahayaan yang ada tidak maksimal. Pencahayaan buatan yang baik dan memenuhi standar dapat dipengaruhi oleh cara pemasangan sumber cahaya pada dinding atau langit-langit, konstruksi sumber cahaya dalam ornament yang dipergunakan, luas dan bentuk ruangan serta penyebaran sinar dari sumber cahaya [13].

Ruangan yang baik memerlukan cahaya yang cukup, tidak kurang dan berlebihan. Kurangnya cahaya yang masuk ke dalam ruangan, terutama cahaya matahari disamping kurang nyaman, juga merupakan media yang baik untuk pertumbuhan dan perkembangbiakan bibit penyakit. Sebaliknya terlalu banyak cahaya dalam ruangan akan menyebabkan silau dan akhirnya dapat merusak mata.

2. Kondisi WC/KM

a. Kebersihan WC/KM

Tabel 4 Hasil pemeriksaan kebersihan KM/WC

\begin{tabular}{ccc}
\hline No & Unit & Kebersihan \\
\hline 1 & WC/KM 1 & Ya \\
2 & WC/KM 2 & Ya \\
3 & WC/KM 3 & Ya \\
4 & WC/KM 4 & Ya \\
5 & WC/KM 1 & Ya \\
6 & WC/KM 2 & Ya \\
7 & WC/KM 3 & Ya \\
8 & WC/KM 4 & Ya \\
9 & WC/KM 5 & Tidak \\
10 & WC/KM 6 & Tidak \\
11 & WC/KM 7 & Ya \\
12 & WC/KM 8 & Ya \\
13 & WC/KM 9 & Ya \\
\hline
\end{tabular}

Berdasarkan data pada tabel 4, dari $13 \mathrm{WC} / \mathrm{KM}$ yang diperiksa ada 2 (15\%) KM/WC yang kondsinya masih terlihat kurang bersih pada bagian lantai dan bak penampungan air. Kondisi kebersihan WC/KM secara keseluruhan sudah bersih, pada bagian lantai dan bak penampungan air. Secara keseluruhan WC/KM dan bagian bowl (closet)terlihat bersih bersih, kondisi lantai di WC/KM tidak licin, tidak ada genangan air pada lantai serta kondisi di dalam tidak tercium aroma bau, sehingga WC/KM cukup aman digunakan.

b. Ventilasi dan Pencahayaan 
Tabel 5 Hasil pengukuran ventilasi dan pencahayaan

\begin{tabular}{|c|c|c|c|c|c|}
\hline \multirow[t]{2}{*}{ No } & \multirow[t]{2}{*}{ Unit } & \multicolumn{2}{|c|}{ luas ventilasi } & \multicolumn{2}{|c|}{ Pencahayaan } \\
\hline & & Persyaratan & Hasil & Persyaratan & Hasil \\
\hline 1 & WC/KM 1 & & $22 \%$ & & $27 \operatorname{lux}$ \\
\hline 2 & WC/KM 2 & & $3,6 \%$ & & $20 \operatorname{lux}$ \\
\hline 3 & WC/KM 3 & & $3,6 \%$ & & $20 \operatorname{lux}$ \\
\hline 4 & WC/KM 4 & & $6,6 \%$ & & 90 lux \\
\hline 5 & WC/KM 5 & & - & & 45 lux \\
\hline 6 & WC/KM 6 & & $7,5 \%$ & & $14 \operatorname{lux}$ \\
\hline 7 & WC/KM 7 & & $22 \%$ & & $18 \operatorname{lux}$ \\
\hline 8 & WC/KM 8 & & $5,5 \%$ & & 50 lux \\
\hline 9 & WC/KM 9 & & $5 \%$ & & 50 lux \\
\hline 10 & WC/KM 10 & & $5 \%$ & & $51 \operatorname{lux}$ \\
\hline 11 & WC/KM 11 & & $7,5 \%$ & & $15 \operatorname{lux}$ \\
\hline 12 & WC/KM 12 & & $6,6 \%$ & & $90 \operatorname{lux}$ \\
\hline 13 & WC/KM 13 & & - & & $15 \operatorname{lux}$ \\
\hline
\end{tabular}

Berdasarkan tabel 5, diketahui dari $13 \mathrm{KM} / \mathrm{WC}$ yang diperiksa 100\% kondisi luas ventilasi belum memenuhi persyaratan yaitu $30 \%$ dari luas lantai, begitu juga dengan intensitas pencahayaan $100 \%$ belum memenuhi persyaratan Kepmenkes RI Nomor 1429/Menkes/SK/XII/ 2006 yaitu 100 lux, hal ini dikarenakan sebagian WC/KM luas ventilasi tidak mencukupi, tidak cross ventilasi serta tidak tersedianya lampu di dalam WC/KM, hanya pada WC mushola yang tersedia lampu dengan intensitas pencahayaan masih rendah. Pencahayaan alami di ruangan yang tidak memenuhi syarat kesehatan mendukung berkembang biaknya organisme seperti bakteri dan jamur. Kondisi ini berpotensi menimbulkan gangguan terhadap kesehatan. Selain itu pencahayaan yang kurang menyebabkan ruang menjadi gelap.

c. Bak Air pada WC/KM

Tabel 6 Hasil pemeriksan bak air pada KM/WC

\begin{tabular}{ccccc}
\hline No & Unit & \multicolumn{3}{c}{ Item } \\
\cline { 3 - 5 } & & Berfungsi & Kotor/Bersih & Keberaadaan Jentik \\
\hline 1 & WC/KM 1 & Ya & Bersih & Tidak ada \\
\hline 2 & WC/KM 2 & Ya & Bersih & Tidak ada \\
3 & WC/KM 3 & Ya & Bersih & Tidak ada \\
4 & WC/KM 4 & Ya & Bersih & Tidak ada \\
5 & WC/KM 5 & Ya & Bersih & Tidak ada \\
6 & WC/KM 6 & Ya & Bersih & Tidak ada \\
7 & WC/KM 7 & Ya & Bersih & Tidak ada \\
8 & WC/KM 8 & Ya & Bersih & Tidak ada \\
9 & WC/KM 9 & Ya & Kotor & Tidak ada \\
10 & WC/KM 10 & Ya & Kotor & Tidak ada \\
11 & WC/KM 11 & Ya & Bersih & Tidak ada \\
12 & WC/KM 12 & Ya & Bersih & Tidak ada \\
13 & WC/KM 13 & Ya & Bersih & Tidak ada \\
\hline
\end{tabular}

Berdasarkan tabel 6, diketahui pada setiap ruang WC/KM disediakan bak/penampungan air. Dari $13 \mathrm{WC} / \mathrm{KM}$ $100 \%$ berfungsi dengan baik, 15\% bak air pada WC/KM masih terlihat kurang bersih (kotor) dan ada terlihat lumut. Di dalam bak air tidak terdapat jentik nyamuk sehingga bak air di WC/KM ini aman dari breading place nyamuk Aedes 
$s p$ yang bisa berpotensi menimbulkan penyakit DBD.

\section{Konstruksi Bangunan}

Hasil observasi dari 13 ruang kelas, $100 \%$ jarak papan tulis dengan meja $>2,5$ $\mathrm{m}$, hal ini sudah memenuhi persyaratan. Kepadatan ruang kelas di sekolah berkisar antara 1,80 m/murid, ini sudah memenuhi persyaratan, yaitu minimal kepadatan kelas $1,75 \mathrm{~m} /$ murid. seluruh ruang bangunan (100\%) dari 23 ruang bangunan yang diamati memiliki langitlangit kuat, kondisi baik, tidak bocor berwarna terang (warna hijau pada ruang kelas, mushola, putih pada laboratorium, ruang guru, perpustakaan, UKS dan ruang bimbingan konseling), mudah dibersihkan dan tinggi nya $>3,25 \mathrm{~m}$ dari lantai serta bersih. Seluruh ruang bangunan memiliki lantai yang kuat, tidak retak, kedap air, dan mudah dibersihkan, tetapi pertemuan antara lantai dan dinding bangunan tidak konus. Lantai ruang bangunan dalam kondisi bagus dan bersih disetiap ruangnya, lantai terbuat dari keramik berwarna putih terang. Terdapat tangga di ruang bangunan sekolah, dengan lebar anak tangga $>30 \mathrm{~cm}$, tinggi anak tangga $>$ $20 \mathrm{~cm}$, dan lebar tangga $\geq 150 \mathrm{~cm}$. Dilengkapi dengan jendela pada setiap ruang bangunannya, jendela dapat dibuka dan ditutup kearah luar, khusus ruang laboratorium dan perpustakaan memiliki besi pengaman pada setiap sisi jendela.

\section{Pembinaan Lingkungan \\ a. Air Bersih}

Sumber air bersih yang sering digunakan di sekolah adalah sumur gali (SGL), letak SGL dari septic tank, > $10 \mathrm{~m}$. Secara kualitas persyaratan air bersih; tidak berwarna, tidak berasa, tidak berbau, bersih dan jernih. Kuantitas air bersih, cukup untuk seluruh keperluan sekolah sehari-hari, ditambah disekolah terdapat tandon untuk menampung air bersih dari sumur. Air bersih yang tidak memenuhi persayaratan dapat menularkan penyakit. Penyakit yang ditularkan melalui air disebut sebagai waterborne disease [1]. Pencemaran air dapat menyebabkan pengaruh berbahaya bagi organisme, populasi, komunitas, dan ekosistem [14].

b. Sampah dan Air Limbah

Terdapat tempat sampah didalam/luar ruangan, di setiap ruangan, tapi masih ada tempat sampah yang dibiarkan terbuka di ruang kelas, walaupun tempat sampah tersebut memiliki tutup. Tersedia tempat pembuangan sampah sementara (TPS), dengan konstruksi terbuat dari semen serta juga terdapat drum, akan tetapi kondisi nya terbuka, pengangkutan sampah dilakukan setiap hari, jarak TPS dengan warung sekolah $<10 \mathrm{~m}$, terletak disamping warung sekolah. Jarak TPS dengan ruang kelas $>10 \mathrm{~m}$. Jarak TPS dengan sumber air bersih $>10 \mathrm{~m}$ dari SGL. Saluran pembuangan air limbah, dengan kondisi disemen (kedap air), mengalir cukup lancar akan tetapi tidak tertutup atau terbuka, jarak penampungan air limbah dengan sumber air bersih $>10 \mathrm{~m}$, tetapi jarak penampungan air limbah dengan warung sekolah $<10 \mathrm{~m}$. Pembuangan air limbah dialirkan ke sumur resapan yang tertutup rapat, begitu juga pada air limbah dari riol sekolah dialirkan kepenampungan dan dilakukan pengolahan.

\section{c. Halaman dan Pekarangan}

Kebersihan, kerapian dan keindahan halaman dan pekarangan di sekolah terlihat bersih dari sampah yang berserakan ataupun tanaman liar, tidak terdapat genangan air dihalaman sekolah serta penataan halaman dan pekarangan sekolah ditata rapi. Terdapat tanaman Perindang dan Hias dihalaman pekarangan sekolah yang ditata rapi. Ada kebun sekolah yang cukup beragam ditata rapi dan sebagian memiliki nama. Terdapat halaman bermain, dan olahraga lingkungan sekolah, terdiri dari lapangan volly, lapangan basket dan lapangan futsal yang memadai dan bersih. Terdapat sarana tempat ibadah (mushola) yang memadai dan kondisinya cukup nyaman dan bersih. Pagar sekolah ini befungsi dengan baik, kondisi pagar terawat dan 
aman serta serasi yang mengelilingi lingkungan sekolah. Penerapan kawasan bebas rokok tidak terlihat ada guru maupun tamu yang ada merokok dilingkungan sekolah.

Kegiatan PSN, di sekolah selalu dilakukan kegiatan jum'at bersih dan salah satu kegiatan yang dilakukan ada melakukan PSN dengan cara 3M (seperti menguras bak penampungan air) yang dilakukan oleh siswa ataupun petugas kebersihan sekolah.

Tempat parkir dan lapangan upacara, Terdapat tempat parkir yang cukup untuk menampug kendaraan siswa/i maupun guru, lokasi parkir guru berada di depan, sedangkan untuk siswa berada di samping dan belakang sekolah serta terdapat lapangan upacara ditengah halaman sekolah yang memadai dan cukup untuk menampung siswa/i.

Kebisingan yang diukur di lingkungan sekolah, berkisar antara 45-55 dBA, yaitu 52 dBA, pada saat dilakukan pengukuran kondisi disekolah tidak ada aktivitas belajar mengajar karena siswa/i beraktivitas di luar kelas. Kebisingan diatas $50 \mathrm{~dB}$ sudah dapat dianggap sebagai kebisingan yang perlu mendapat perhatian karena menggangu kenyamanan pendengaran[15]. Kebisingan disekolah masuk dalam zona B dan tingkatan kebisingan ini masih dalam maksimum diperbolehkan yaitu 55 dBA [16].

Tabel 7. Rekapitulasi Penilaian Sanitasi lingkungan Sekolah di SMA Negeri 1 Martapura

\begin{tabular}{clccc}
\hline No & \multicolumn{1}{c}{ Variabel } & Nilai & Nilai Maksimum & Cakupan (\%) \\
\hline 1. & Kebersihan Ruang Bangunan & 140 & 200 & 70 \\
2. & Kondisi WC/KM & 585 & 800 & 73,12 \\
3. & Konstruksi Bangunan & 575 & 600 & 95,83 \\
4. & Pembinaan lingkungan & 2060 & 2.400 & 85,83 \\
\hline \multicolumn{2}{c}{ Jumlah } & 3.360 & 4.000 & 84 \\
\hline
\end{tabular}

Berdasarkan tabel 7, nilai keseluruhan sanitasi lingkungan sekolah di SMA Negeri 1 Martapura sebesar 3.360 (84\%), dari total penilaian 4.000, penilaian ini masih kurang 640 poin $(16 \%)$ dari total nilai maksimum.

\section{KESIMPULAN DAN SARAN}

Kondisi sanitasi di lingkungan sekolah secara umum sudah baik dan memenuhi persyaratan sekolah sehat. Nilai sanitasi lingkungan sekolah 3.360 dari total peniaian 4.000 (84\%), penilain ini masih kurang 640 poin (16\%) dari total nilai maksimum. Permasalahan sanitasi di SMA Negeri 1 Martapura, luas ventilasi pada ruang kelas dan $\mathrm{WC} / \mathrm{KM}$ belum memenuhi persyaratan, beberapa ruang intensitas pencahayaanya belum memenuhi persyaratan, jarak WC/KM, TPS, penampungan limbah dengan warung sekolah, dan saluran pembuangan air limbah yang terbuka.
Diharapkan sekolah melengkapi lampu KM/WC, saluran pembuangan air limbah dengan konstruksi tertutup, memindah TPS yang ada, ketempat yang lebih jauh atau berjarak lebih dari $>10 \mathrm{~m}$ dari warung sekolah.

\section{KEPUSTAKAAN}

1. Budiman Chandra, 2006, PengantarKesehatanLingkungan, EGC. Jakarta.

2. Sarudji Didik, 2010, KesehatanLingkungan, Karya Putra Darmawati. Bandung.

3. Notoatmodjo, Soekidjo.2010. Promosi Kesehatan Teori dan Aplikasi, RinekaCipta. Jakarta

4. Undang-undang No. 36 Tahun 2009 pasal 79 tentang kesehatan.

5. Peraturan Menteri Pendidikan Nasional Republik Indonesia Nomor 57 tahun 2009, tentang pemberian bantuan pengembangan sekolah sehat. Jakarta. 
6. Notoatmodjo Soekidjo, 2002. Metodologi Penelitian Kesehatan. Rineka Cipta: Jakarta

7. Marzuki dan Gunawan, 2002. Statistik Kesehatan .UGM. Yogjakarta.

8. Keputusan Menteri Kesehatan RI Nomor 1429/Menkes/SK/XII/2006 tentang pedoman penyelenggaraan kesehatan lingkungan sekolah.Jakarta.

9. Santoso Imam, 2015, Sanitasi Tempat-tempat Umum. Gosyen Publishing.Yogyakarta

10. Notoatmodjo Soekidjo, 2003, IImu Kesehatan Masyarakat Prinsip-Prinsip Dasar, Rineka Cipta. Jakarta

11. RiviwantoMuchsin\&dkk, 2011, PenyehatanPemukiman.Gosyen Publishing. Yogyakarta.

12. Pudjiastuti, L, dkk. 1998. Kualitas Udara dalam Ruang. Departemen Pendidikan dan Kebudayaan : Jakarta.

13. Istiqomah dan Hanas dalam Kasjono, ed. 2011. Penyehatan Pemukiman. Goysen Publishing: Yogyakarta.

14. Soegianto Agoes, 2005, IImu Lingkungan Sarana Menuju Masyarakat Berkelanjutan. Airlangga University.Surabaya.

15. Wardhana, Wisnu Arya. 2007. Dampak Pencemaran Lingkungan di Yogyakarta. Yogyakarta.

16. Mukono H.J, 2006, Prinsip Dasar Kesehatan Lingkungan. Pusat Penerbitan dan Percetakan Unair. Surabaya. 
